\title{
Dermatopathology in respect to bovine cutaneous streptothricosis with clinical observations at Dinajpur of Bangladesh
}

\author{
Mst. Sogra Banu Juli ${ }^{1}$, Md. Fazlul Hoque ${ }^{1}$, Begum Fatema Zohara ${ }^{1}$, \\ S. M. Harun-ur-Rashid ${ }^{2}$, Md. Nazrul Islam ${ }^{2}$, Md. Siddiqur Rahman ${ }^{3}$, Hee-Jong Song ${ }^{4}$ \\ ${ }^{1}$ Department of Medicine, Surgery \& Obstetrics and ${ }^{2}$ Department of Pathology \& Parasitology, \\ Hajee Mohammad Danesh Science and Technology University, Dinajpur-5202, Bangladesh, \\ ${ }^{3}$ Department of Medicine, Bangladesh Agricultural University, Mymensingh, Bangladesh, \\ ${ }^{4}$ Korea Zoonoses Research Institute, Chonbuk National University, Jeonju 561-756, Korea
}

(Received 6 December 2010, accepted in revised from 22 March 2010)

\section{Abstract}

Dermatopathologic findings on cutaneous streptothricosis (bovine dermatophilosis) were conducted in Dinajpur of Bangladesh for one year. The animals were examined clinically at hospital during the physical visit of the affected animals and clinical manifestations and patients' history were recorded. The gross lesions were systematically examined, noted and categorized. An impression smear was made by the skin scraps, stained with Gram's stain and examined microscopically for the presence of causative bacteria. The suitable sizes of skins of 3 animals typically affected with dermatophilosis were collected surgically from the animals, and prepared for the histopathological study. The cardinal clinical features and gross lesions were characterized as paint-brush cutaneous surface with matted hairs, scab and crust formation, roughened coat; histopathologically as hyperkeratosis, parakeratosis, typical "palisading encrustations", extensive proliferation of coccoid shaped, bluish coloured bacteria (zoospores) in the cells of the outer rootsheath of the hair follicles, separation of keratinized layer from the epidermal epithelium, epidermal hyperplasia, densely cellular dermis with moderate destruction of glandular structures. Coccoid shaped gram positive organisms which form multidimensional arrangement were also observed by impression smear. The clinical signs, gross lesions, morphology of the organisms, staining properties, and histopathological features of the affected skin were diagnostic criteria for the bovine cutaneous streptothricosis.

Key words : Dermatophilosis, Dermatopathology, Cutaneous streptothricosis, Bovine

\section{INTRODUCTION}

Dermatophilus congolensis is a gram-positive, nonacidfast, facultative anaerobic actinomycete bacterium which causes an exudative, acute or chronic skin condition termed as dermatophilosis (Woldemeskel and Taye, 2002; Chatikobo et al, 2004; Loria et al, 2004). Cutaneous streptothricosis, cutaneous actinomycosis, Senkobo disease, proliferative dermatitis in cattle, lumpy wool disease or strawberry foot rot in sheep synony-

*Corresponding author: Mst. Sogra Banu Juli, Tel. +88-01729-519747, Fax. +82-63-270-3780, E-mail. julivetmed@gmail.com mously and mycotic dermatitis erroneously have been used to state the dermatophilosis elsewhere (Scott, 1988; Jones et al, 1997a; Radostits et al, 2007; Fraser et al, 2008). The organism has a broad host range including humans (Zaria, 1993).

Clinically infected (Oduye, 1976; Abu-Samra, 1978) or latently (Stewart, 1972) or asymptomatic clinically infected reservoirs (Fraser et al, 2008) and the arthropods (Howard, 1986) are the major sources of infection. The organisms are suspected as the skin commensals lying dormant in dry scabs and crusts upto 42 months (Oduye, 1989; Martinez and Prior, 1991). Various recommended 
and controversial predisposing factors that break the natural barriers of the integument and play the crucial role in the initiation, development, prevalence, seasonal incidence, and transmission and establishment of infection (Radostits et al, 2007; Fraser et al, 2008). The organism cannot penetrate the intact skin, thus minor trauma in the skin is prerequisite. Merely high humidity (moisture) weakens the skin barrier, facilitates the germination, maturation and release of zoospores from the preexisting lesions, their subsequent cutaneous penetration, increases the activity of the arthropod vectors and contributes indirectly to the spread of the lesions (Fraser et al, 2008).

Bovine dermatophilosis is clinically observed in 3 stages (Fraser et al, 2008): firstly paint-brush lesions with matted hairs; secondly crust or scab formation as the initial lesions coalesce; and thirdly accumulations of cutaneous keratinized material forming wart-like lesions that are $0.5-2 \mathrm{~cm}$ in diameter. Several clinical features and gross morbid lesions rather than those stated above have also been mentioned elsewhere by many investigators (Radostits et al, 2007; Fraser et al, 2008).

Histopathological examinations of samples reveal hyperkeratosis, parakeratosis, orthokeratosis, acanthosis, and folliculitis (Msami et al, 2001; Yeruham et al, 2003). During the initial period (from day 4 to 14) the inflammatory infiltration in the epidermis is composed mostly of neutrophils and subsequently (in chronic cases) of mononuclear cells (Ambrose, et al, 1999; Msami et al, 2001; Yeruham et al, 2003). In acute cases, microabscesses also occurs (Yeruham et al, 2003). Necrotic areas within the granular layer of the epidermis may be noted. Sometimes the typical forms of D. congolensis (filamentous hyphae) may be seen within the epidermis and hair follicles (Msami et al, 2001; Yeruham et al, 2003).

\section{MATERIALS AND METHODS}

\section{Experimental animals, research area and research period}

The clinical study emphasizing dermatopathology of the bovine cutaneous streptothricosis was conducted at Veterinary Teaching Hospital (VTH) of Hajee Mohammad Danesh Science and Technology University (VTHHSTU) in Dinajpur of Bangladesh. The course of the study was one year from March-2009 to February-2010 and the animals submitted to the hospital for the diagnosis and therapeutic purposes were considered as the experimental animals.

\section{Clinical Findings}

The animals submitted to the veterinary teaching hospital were examined; the clinical cases and the clinical manifestations were recorded. The clinical signs of the cutaneous streptothricosis were also noted during the physical visit of the affected animals and the farmer's complaints in relation to the disease were also emphasized and recorded.

\section{Examination of the skin scraps}

An impression smear was made by the skin scraps, stained with Gram's stain and microscopically examined following a standard procedure (Cowan, 1979) to demonstrate the bacteria. The morphology of the bacteria, staining properties and their arrangements were studied and noted.

\section{Microscopic examination of skin scraps}

Skin scraps containing exudates was taken from the lesions of the animal typically affected with dermatophilosis. The skin scrap was placed on a dry, cleaned petridish and brought to the bacteriological laboratory with necessary precautions. An impression smear with the collected exudates was made. The slide was held over the flame for a few seconds. Then the slide was flooded with Gram's iodine solution and allowed to remain for 30 60 seconds. The stain was poured off and washed in running water. The film was then decolorized with addition of acetone for 2 3 seconds and washed in running water. The film was counter stained with safradine solution was allowed to act for about 3 minutes and washed in running 
water. The slide was air dried and examined under microscope using oil immersion. The result was recorded and the image of the film was taken using a digital camera.

\section{Dermatopathological study}

The submitted patients affected with dermatophilosis were examined by both distant and close inspection of the skin of the diseased animals. The gross morbid lesions of the disease were systematically examined, noted, categorized and presented in Table 1.

The suitable sizes of skins of 3 bovine animals typically affected with dermatophilosis were collected surgically taking required precautions from the live patients for further histopathological study. A portion of the normal skin collected from the abattoir was also included in the present study to compare with the histopathological lesions of the affected skins.

The representative cutaneous tissues were collected and preserved at $10 \%$ buffered formalin solution and subsequently processed, embedded with paraffin, sectioned and stained with haematoxylin and eosin for histopathological examination (Luna, 1968).

\section{Protocol of surgically collection of affected skin}

Surgical instruments were sterilized by boiling and re- straining of animals was performed by casting. Local anaesthetic was applied subcutaneously following site selection and waited for few minutes for anaesthetic action. Folding of skin was done by artery forceps and excess folded portion of skin was excised and subsequently sutured with nylon threads. Locally application of cotton admixing with Tincture of iodine was done as counter irritant. Antibiotic course was maintained and hygienic measures were suggested to avoid secondary complications. Suture was removed at 7 days after operation.

\section{Protocol of processing of collected skins for histopathology}

Collected skin samples were preserved at 10\% formalin solution for at least 3 days and trimming of preserved samples was done at suitable sizes. Overnight watering of tissues was done and subsequently dehydration was performed in a series of ascending grades of alcohol (50\% alcohol: 1hour, 70\% alcohol: 1hour, 80\% alcohol: 1hour, 95\% alcohol: 1 hour and 100\% alcohol: 3 changes and 1 hour for each change). Chloroform treatment ( 2 changes and 1.5 hours for each change) and impregnation by paraffinization at melting point $\left(560^{\circ} \mathrm{C}\right)(2$ changes and 1.5 hours for each change) were followed. The cooked tissue samples were blocked and subsequently sectioned at 5 7 $\mu \mathrm{m}$ in thickness, placing

Table 1. Typification of the gross morbid lesions of bovine dermatophilosis

\begin{tabular}{|c|c|c|c|c|c|c|c|c|c|c|}
\hline Clinical features & $\begin{array}{c}\text { Face } \\
\text { and } \\
\text { ear }\end{array}$ & $\begin{array}{l}\text { Ventral } \\
\text { neck }\end{array}$ & $\begin{array}{c}\text { Topline } \\
\text { and lateral } \\
\text { abdominal } \\
\text { surfaces }\end{array}$ & $\begin{array}{c}\text { Brisket, } \\
\text { axillae and } \\
\text { groin }\end{array}$ & Buttock & $\begin{array}{l}\text { Distal } \\
\text { limbs }\end{array}$ & $\begin{array}{l}\text { Perineum } \\
\text { and Tail }\end{array}$ & $\begin{array}{l}\text { Scrotum } \\
\text { and } \\
\text { prepuce }\end{array}$ & $\begin{array}{c}\text { Udder and } \\
\text { teats }\end{array}$ & Generalized \\
\hline $\begin{array}{l}\text { Alopecia and/or } \\
\text { matted hairs }\end{array}$ & +++ & +++ & +++ & +++ & ++ & +++ & ++ & + & + & + \\
\hline Pruritus & + & + & - & - & - & + & - & - & - & - \\
\hline $\begin{array}{l}\text { Cutaneous } \\
\text { thickening }\end{array}$ & +++ & + & + & + & + & +++ & +++ & - & - & - \\
\hline Erythema & + & ++ & ++ & +++ & + & +++ & + & + & + & - \\
\hline Hyperpigmentation & +++ & - & + & + & + & +++ & + & + & ++ & - \\
\hline Exudation & + & + & + & + & + & + & + & + & + & + \\
\hline $\begin{array}{l}\text { Scab and/or crust } \\
\text { formation }\end{array}$ & ++ & +++ & +++ & +++ & ++ & +++ & ++ & ++ & ++ & ++ \\
\hline Myiasis & - & - & - & +++ & - & + & - & - & - & - \\
\hline
\end{tabular}

- : Absent, + : Mild, ++ : Moderate, +++ : Severe/Marked. The one more locations of lesions of bovine dermatophilosis were reflected by the same clinically affected animal. 
on water bath, taking on a glass slide and air dried.

\section{Protocol of routine haematoxylin and eosin ( $H$ \& E) staining}

Xylene treatment ( 3 changes and 3 minutes for each change) of the sectioned tissue samples and rehydration in a descending grades of alcohol $(100 \%$ alcohol: $2 \mathrm{mi}-$ nutes, 95\% alcohol: 2 minutes, 80\% alcohol: 2 minutes, 70\% alcohol: 2 minutes, distilled water: 10 minutes) was done. Staining of the tissue with haematoxylin(10 15 minutes) and eosin (30 minutes) and then dehydration in an ascending grades of alcohol $(80 \%$ alcohol: few dips, 95\% alcohol: few dips, 100\% alcohol: few dips) was done. Xylene treatment ( 3 changes and 3 minutes for each change) and mounting with Canada balsam was followed. Examinination of the tissue sample was done under microscope using both low and high power objectives.

\section{Photography}

The images of impression smear and the histopatho- logical lesions were directly taken from the microscope by a digital camera, simply modified in computer and set in the present study for the better illustration of the results.

\section{RESULTS AND DISCUSSION}

\section{Clinical cases}

A total 681 clinical cases were recorded among which 71 cases were primarily presumptive diagnosed and registered as cutaneous streptothricosis in this hospital during the course of the experimental period. The disease in the study area was not very uncommon and $10.43 \%$ cases were suspected as bovine cutaneous streptothricosis. The disease as well as its etiological agent (Dermatophilus congolensis) was studied and identified in the climatic context of Bangladesh(Nooruddin and Khaleque, 1986a, b).

Bovine cutaneous streptothricosis is distributed worldwide (Radostits et al, 2007). The greatest prevalence of the disease is remarked in the tropical and subtropical
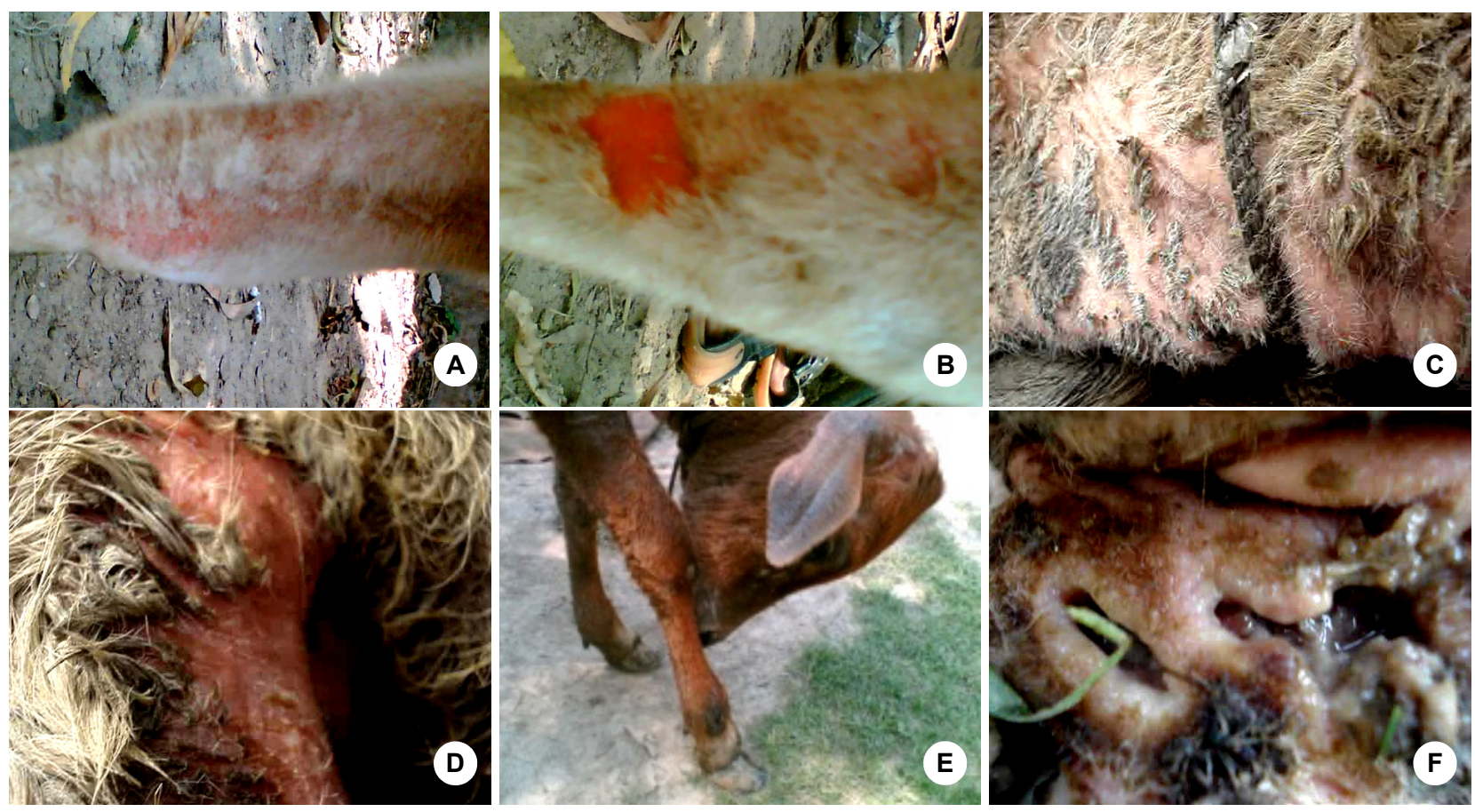

Fig. 1. Clinical features: Erythema(A), Paint-brush lesion(B), Incrustations (C), Matted hairs with alopecia (D), Pruritus (E) and Porous skin with scab formation and complication with maggot formation $(\mathrm{F})$. 
countries causing substantial economic losses in the livestock sector (Makinde, 2004; Ambrose et al, 1999; Koney, 1996; Zaria, 1993). The latently infected (Stewart, 1972) clinically infected or the recovered animals act as the principal sources of infection (Stewart, 1972; Lofstedt, 1983; Martin, 1983; Mollowney and Fadok, 1984).

\section{Clinical features}

In the present study the stages of dermatophilosis were classified into two major categories based on the degree of severity of the disease and the level of its complication: acute (complicated cases having maggot infestation and increased severity) and subacute (uncomplicated cases, animals with preliminary stage of the disease, and the stage of recovery), whereas three clinical stages, acute, subacute and chronic or mild were also mentioned in the literature (Fraser et al, 2008). Mild form of the disease was usually not found in this study. The exact etiology about this fact was not clearly known and this could be due to the ignorance of the farmers, lack of identifying capacity and keeping their affected animals untreated until the development of severe lesions.

The disease starts as erythema of the skin (Abdullahi,
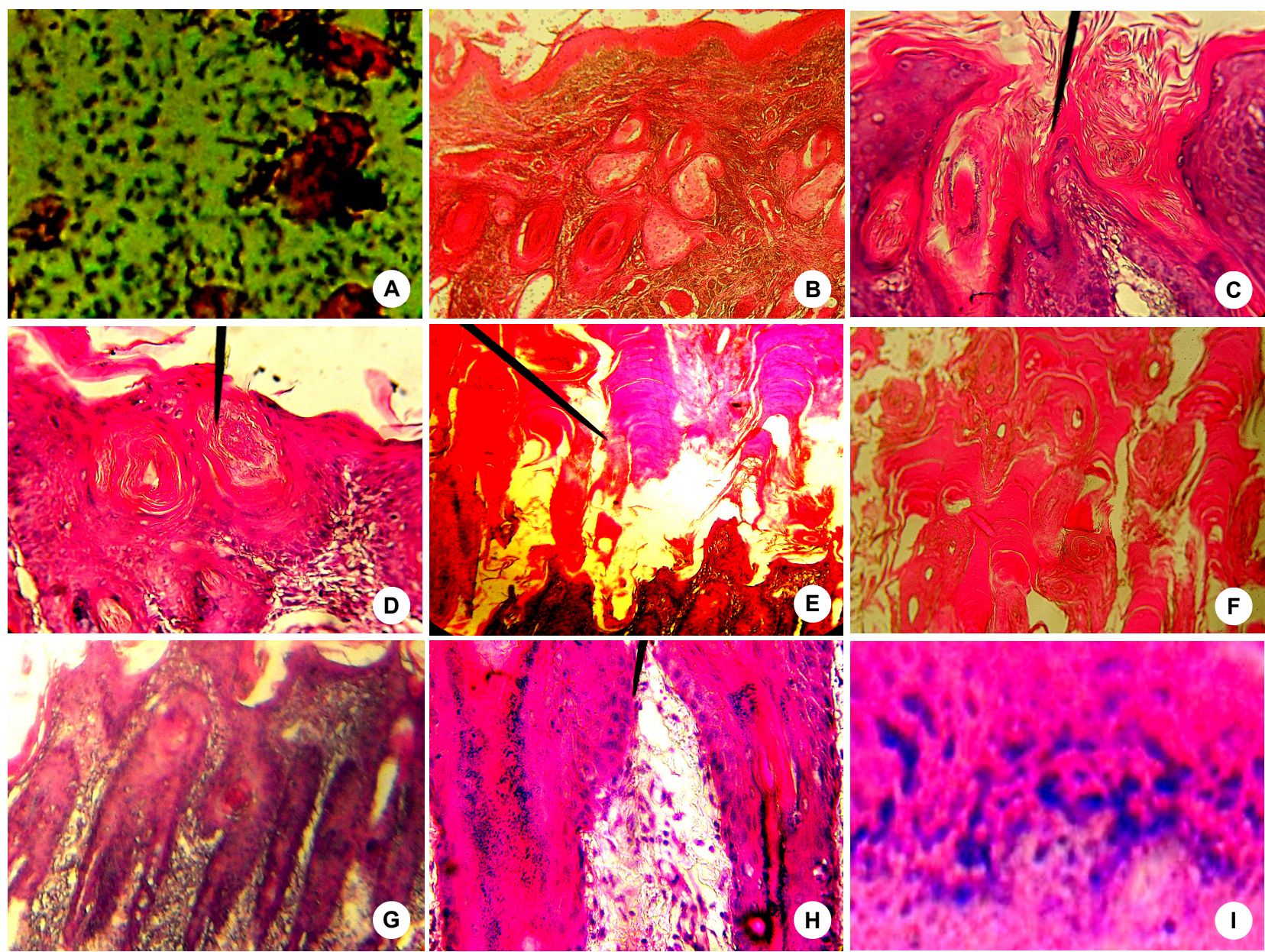

Fig. 2. Histopathological features. Impression smear made from exudate stained with Gram's stain showed bacteria (A), Normal skin section possessing glandular structure (arrow) (B), Dermatophilosis affected tissue section (High objective $\times 400$ (C), Intraepidermal accumulation of keratin fibers (D), Palisading of the corneal layer (E), Typical palisading encrustation of the corneal layer (F), Densely cellular dermis, (arrow) (G), Multidimensional (white arrow) and longitudinal (yellow arrow) multiplications of Dermatophilus sp. (coccoid shaped) (H), Huge bacteria in the outer rootsheath of hair follicle (coccoid shaped bluish bodies with hazy outlines) (I). 
2001; Ali-Emmanuel et al, 2003; Dalis et al, 2007) which is subsequently followed by matted hairs with paint-brush lesions, scab formation, varying degrees of encrustations, localized to generalized areas of affections, roughened coat, varying degrees of weakness, dehydration, depression, weight loss and similarly described by many authors (Bwangamoi, 1976; Oduye, 1976; Cameron, 1984; Jones et al, 1997a; Vegad and Katiyar, 2003; Radostits et al, 2007; Fraser et al, 2008) (Fig. 1). However the animals at VTH-HSTU covered the clinical manifestations stated as above which was characteristics for the disease.

\section{Gross morbid lesions}

The gross morbid cutaneous lesions of dermatophilosis recorded in the present study were pathologically characterized as erythema, matted hairs, serosanguineous exudation, scab and crust formation, hyperkeratosis, parakeratosis, lesions with varying degrees in sizes and shapes, tiny lesions coalesce to form larger ones, lesions with maggot infestations, lesions were deeply porous at maggot infested areas and similarly described (by Jones et al, 1997a; Vegad and Katiyar, 2003; Radostits et al, 2007 and Fraser et al, 2008) (Fig. 2). The types of gross pathological lesions were presented in Table 1.

\section{Impression smears}

Impression smears prepared from the skin scraps containing exudates showed gram positive, coccoid shaped organisms which were scatteredly arranged. Comparatively quite similar statements on bacterial morphology and staining properties are well documented elsewhere (Yeruham et al, 2003; Dalis et al, 2009). However, isolation, identification and typification by bacteriological cultivation and biochemical tests were not done and these are prerequisites for the bacterial identification.

\section{Histopathological features}

The skins of the animals typically affected with dermatophilosis were collected, preserved, processed and stained for histopathological observation. The characteristic histopathological lesions of the epidermis were hyperkeratosis, parakeratosis (nuclei in the pink keratinized layer), typical palisading encrustations, filamentous structures in the keratinized layers, hyperplasia of the epidermal epithelial cells, ballooning degeneration (vacuolated cells), the dermis was densely cellular(inflammatory reactive cells), folliculitis, glandular destruction and fibroplasia. The bacterial growth was observed in the cells of the outer rootsheath of the hair follicles. These were bluished bodies with hazy outlines, coccoid shaped and multidimentational in arrangements within the tissues. These statements were agreed with many authors (Vegad and Katiyar, 2003; Yeruham et al, 2003; Radostits et al, 2007; Dalis et al, 2009). The morphology of the organisms both in impression smears and in tissues was very similar.

Conclusively, the cardial clinical features, gross morbid lesions, histopathological images and the presence of characteristic bacterial organisms both in impression smears and in the cells of the outer rootsheath of hair follicles were strongly recommended bovine cutaneous streptothricosis.

\section{ACKNOWLEDGMENT}

The authors would like to thank Professor Dr. Md. Abu Hadi Noor Ali Khan, Department of Pathology, Bangladesh Agricultural University, Mymensingh, Bangladesh, for his valuable suggestions, constructive critisms and judicious comments during MS Thesis evaluation.

\section{REFERENCES}

Abdullahi US. 2001. Chemotherapeutic and chemopro-phylactic control of bovine dermatophilosis. Ph.D. Thesis, Ahmadu Bello University, Zaria, Nigeria.

Ali-Emmanuel N, Moudachirou M, Akakpo JA, Quentin-Leclercq J. 2003. Treatment of bovine dermatophilosis with Senna alata, Lantana camara and Mitracarpus scaber leaf extracts. J Ethnopharmacol 86(2-3): 167-171.

Abu-Samra MT. 1978. Dematophilus infection: The clinical disease and diagnosis. Zentralblatt Veterinary Medicine 
Series B 25(8): 641-651.

Ambrose NC, Lloyd D, Maillard JC. 1999. Immune responses to Dermatophilus congolensis infections. Parasitol Today 15(7): 295-300.

Bwangamoi O. 1976. Economic aspects of streptothricosis in livestock 20 infection in animals and man. New York, Academic Press: 292.

Cameron RDA. 1984. Skin diseases of the pig. Sydney, University of Sydney Post-Graduate Foundation in Veterinary Science. Veterinary Review Number, 23.

Chatikobo P, Kusina NT, Hamudikuwanda H, Nyoni O. 2004. A monitoring study on the prevalence of dermatophilosis and parafilariosis in cattle in small holder semi-arid farming area in Zimbabwe. Trop Anim Health Prod 36(3): 207-215.

Cowan ST. 1979. Cowan and Steel's Manual for the identification of medical bacteria. 2nd eds. Cambridge University Press.

Dalis JS, Kazeem HM, Makinde AA, Fatihu MY. 2009. Distribution of lesions of dermatophilosis in cattle, sheep and goats in Zaria and Jos, Nigeria. J Anim Vet Adv 8: 385-388.

Fraser CM, Bergeron JA, Aiello SE. 2008. The merck veterinary manual. A handbook of diagnosis, therapy, disease prevention and control for the veterinarian. Merck \& Co., Inc. Press, USA.

Howard JL. 1986. Current veterinary therapy: food animal practice. 2nd eds, Philadelphia, WB Saunders Co: 610-611.

Jones TC, Hunt RD, King NW. 1997a. Veterinary Pathology. 6th eds. Williams and Wilkins, USA.

Koney EBM. 1996. Dermatophilosis in Ghana: Effect on the livestock industry. In: Morrow AN, Koney EBM(edition), Proceeding of a workshop on the control of Amblyoma variegatum and associated diseases. Trop Anim Health Prod (2, Suppl) 28: 39-89.

Lofstedt J. 1983. Dermatologic diseases of sheep. Vet Clin North Am Large Anim Pract 59(3): 427-448.

Loria GR, Babera EI, Monteverde V, Piraino C, Caracappa S. 2004. Dermatophilus congolensis: the disease in Italy. Large Anim Rev 10(4): 212-214.

Luna LG. 1968. Manual of histopathologic staining methods of the Armed Forces Institute of Animals (3rd edition). McGraw-Hill Book Company, London.
Makinde AA, 2004. Dermatophilosis in animals and man: Recent studies on Dermatophilus congolensis. VJVS 1: 87-102.

Martin WB. 1983. Diseases of sheep. Oxford, Blackwell Scientific Publications, Inc.

Martinez D, Prior P. 1991. Survival of Dermatophilosis congolensis in tropical clay soils submitted to different water potentials. Vet Microbiol 29(2): 135-145.

Mollowney PC, Fedok VW. 1984. Dermatologic diseases of horses. Part II. Bacterial and viral skin diseases. Comp Cont Ed. 6: S16.

Msami HM, Khascagi D, Schopl K, Kapaga AM, Shitahara T. 2001. Dermatophilus congolensis in goats in Tanzania. Trop Anim Health Prod 33(5): 367-377

Nooruddin M, Khaleque MA. 1986a. Clinical features of bovine dermatophilosis. Bangladesh Vet 3(1-2): 3-5.

Nooruddin M, Khaleque MA. 1986b. Prevalence of bovine dermatophilosis in Bangladesh. Indian J Anim Sci 56(3): 337-338.

Oduye OO. 1976. Bovine streptothricosis in Nigeria. In: Lloyd DH, Sellers KC: Dermatophilus Infection in Animals and Man. New York, Academic Press: 2.

Oduye OO. 1989. Association of diseases with generalized dermatophilosis infections. Discussion at a workshop on dermatophilosis. International Veterinary Dermatophilosis Conference, September, Dijon. France.

Radostits OM, Gay CC, Hincheliff KW, Constable PD. 2007. Veterinary medicine. 10th eds, Elsevier: 1048-1051.

Scott DW. 1988. Large animal dermatology. WB Saunders Company, Philadelphia, USA: 136-146.

Stewart GH. 1972. Dermatophilosis: A skin diseases of animal and man. I. Vet Rec 91(2): 537-555.

Vegad JL, Katiyar AK. 2003. A textbook of veterinary special pathology (Infectious diseases of livestock and poultry). International Book Distributing Co. India.

Woldemeskel M, Taye G. 2002. Prevalence of bovine dermatophilosis in tropical highland region of Ethopia. Trop Anim Health Prod 34(3): 189-194.

Yeruham I, Elad D, Perl S. 2003. Dermatophilosis in goats in the Judean foothills. Revue de Médicine Vétérinaire 12: 785-788.

Zaria LT. 1993. Dermatophilus congolensis infection (dermatophilosis) in animals and man! An update. Comp Immunol Microbiol Infect Dis 16(3): 179-222. 